\title{
Research on the In-depth Integration of Education Information and the Innovation Education in Colleges and Universities
}

\author{
Tian $\operatorname{Lan}^{1,2}$ \\ ${ }^{1}$ College of Art and Design, Changchun University of Technology, Changchun City, Jilin Province, \\ China, 130012 \\ ${ }^{2}$ Shih Chien University, Chinese Taipei, 10462
}

Lantian_2016@163.com

Keywords: Education information; Innovation at colleges and universities; Information technology

\begin{abstract}
This paper mainly studies and discusses the significance of education information and innovative talents, describes the profound significance of promoting innovation at colleges and universities as well as constructing education information, and briefly introduces the current development of information education. This paper also mentions the ways to construct information education at colleges and universities and connecting colleges and universities and analyzes our main tasks and each task in detail, providing valuable reference for future educational mode.
\end{abstract}

\section{Introduction}

We all know that with the development of science and technology, the current human society has entered the information age, and the ways of learning and education have been completely changed. On the global scale, we should conform to the requirements of the times, extensively apply modern information technology, and promote the development and reform of education. At present, China has already been popularizing information education and the education information has been upgraded from the basic stage to the application stage, in the face of this new teaching mode, colleges and universities should seize the opportunity, get to know more education information, and make full use of information technology in education to cultivate students' innovative spirit and ability, thus obtaining the great development of education. It has far-reaching significance on promoting the quality of education, promoting education to be fair, and building all-round talents. All departments should attach great importance to information education, accelerate the construction of information education, enhance the sense of urgency and responsibility.

\section{The Significance of Education Information and the Present Development Situation}

Education information is to "drive education modernization with education information, crack problems that restrict the development of education in our country, promote the reform and innovation of education". As part of the social information refers to use computer technology in the daily teaching, multimedia technology and network communication technology, technology as the foundation and increase reform, make it conform to the requirements of the development. Facing severe challenges in the 1990s to the present, the government has promulgated and implemented many projects and political reform measures to get the basis for the development of our education information technology, let education information promote education fairness and improve the basic role of the quality of education and innovation education mode to play. At the same time, the education information still has a lot of shortcomings, education information at present still very grim. As a new mode of education of information technology in education can be in different time and space for students of education, let more people learn, but also made it more convenient to learn from the best education resources, education information will has become the preferred mode you lifelong learning. Education information is a kind of process based on innovative education, which can be used to train creative talents effectively.

At present, the education information obtained the very big development, including four aspects: 
(1) information technology education environment construction, mainly including all kinds of application Campus: campus network, CAI classroom, digital library, teaching management system. (2) information resources construction, and the main contents are: electronic lesson plans, multimedia course, test questions library, case teaching, network course, (3) construction of information organization includes: institutions in education information and technology teachers, relevant system construction improve relevant policies such as (4) information technology industry currently many enterprises are involved in the resources of campus network by using system integration and related services to.

\section{The Significance of Innovative Talents}

The development of human society cannot do without talents. Talent is the main driving force of social progress, innovative talent is the most outstanding talent resource, can lead to social and economic development, the information society of today, talent is the object that every country to snatch each other, to improve the development of their national economy, if you can the cultivation of innovative talents is equivalent to grasp the first driving force of economic development, to provide power "in Chinese innovative talents of the era value is mainly for the development of the national economy, accelerate socialist modernization, enhance the core competitiveness of the country, promoting the construction of innovation oriented country, enhance the Party's ruling capacity. From the legal system of innovative talents, the basic system, relevant laws and policies and so on has been related to the establishment of a sound system. In the constitution, freedom of thought was written into the constitution training of high-level talent is the goal of college, universities and colleges should be to improve the quality of talent as the core, strengthen personnel training mode, innovative thinking, innovative consciousness and innovative ability also made innovations, known as the innovative talents, personality is usually outgoing, strong curiosity, risk-taking, with strong will feature. Generally speaking, innovative talents have the following characteristics: (1) strong learning ability (2) curiosity and thirst for knowledge is relatively strong. (3) professional knowledge is more solid and has a strong professional standard. (4) can live in harmony with others. (5) self-confidence can be a difficult task.

Innovation ability is not the embodiment of a single ability, but the ability of a variety of intertwined and produce a comprehensive ability, in the creative thinking, rigorous problem awareness, reasonable imagination can be reflected in several aspects. The so-called innovation is the exploration of the unknown things, can be reflected in a strong sense of knowledge of a person, to be successful to have a good spirit of cooperation, a strong will, a sense of achievement and other aspects of the foundation. Only full training of innovative talents in order to provide information for the education of fresh blood, so that it can be fully played the role of.

\section{The Significance of Deepening the Education Information and Promoting the Innovation Education in Colleges and Universities}

Today's society has become the world of knowledge, and innovative talent is the most important of talent, social development is not to create a new type of talent, innovation and talent is the main driving force of social development. Innovative education level determines the training level of the level of talent is to cultivate innovative talents guarantee and the significance of education information construction: an important step to realize the modernization of education, is conducive to the improvement of the quality of the whole people, promote the cultivation of innovative talents, promote the development of education theory and promote the development of education information industry. Impact on the construction of the school: education information is an important part of school construction and personnel training, the level of construction is an important symbol of the school's overall level of school running, school image and status. The practice of innovative education as a complete educational system to in-depth study of the impact of innovative education quality the key factors and its mechanism of action, for the reform of education and teaching, improve the quality of innovative talents, improve higher education 
innovation practice education system is a very important and need to focus on resolving the problem. Education information as a model of the continuous reform and innovation of China's higher education is education idea and education mode reform, to promote education fairness and quality of education reflected in the huge potential, is the only route to the students. Students' innovative thinking and innovative ability can be very good to improve. On Cultivation of talents and to the country's economic development has a very special role, education information can be very good to improve the students' learning enthusiasm, cultivate students love to learn to learn personal hobby, also can create a good learning environment, culture is a basic guarantee of the new talents. College students as the country through the examination of the choice of talent in general have the potential for innovation, if through a reasonable and effective way to improve the students' ability to innovate. Also information education can cultivate talents for our various industries and make workers improved the overall quality, as an important part of education information, actively looking for exploration of information technology in education and innovation education of the depth of integration of innovative education development has a strong supporting role.

\section{Action Plan}

In order to achieve national information technology education must be in a few implemented: quality resource sharing, education information management, school information, sustainable development ability, and information based on the ability of five. These five aspects are very specific and in line with the actual, makes people feel happy is in about the capacity for sustainable development and the basis of the information capacity in vying for the world's advanced level of the target. Promoting sustainable development capacity building is the focus of education information, to put this policy into good, we must continue to work in the following aspects:

Deepen the Understanding of the Credibility of Information. Establish the technical system of education information and strategic research extensive education skills training, promotion of education information, the construction standards (including a plurality of information technology education with experimental equipment and results of the implementation of the new transformation base, technology education research and development with our own independent property rights of education information equipment, information technology and research the teaching mode between the law, through the experimentation area with pilot schools, provide a relatively more systematic and standardized solutions to information technology, equipment and education to get better fusion, construction of some related research institutions of the analysis of domestic and foreign development status, evaluate the current development progress.) To strengthen the ability of information technology personnel training, in the current form of information technology education is to improve the quality of education is the main magic weapon, is the social development of the choice is the inevitable requirement of social development. If information education is not a certain value, to achieve the goal will be difficult. In the process of developing information education, we have to create a suitable environment for innovation, and a good atmosphere of activities. Not only on the surface of the work we need to radically reform, so that the protection and support innovation, so that more innovative consciousness play out. At the same time also to the school leadership and teachers were related training, through a series of training methods, such as lectures, online courses, technical training and other ways to learn. To establish a team of education in line with the requirements of modern education, otherwise the education information is not supported by the social spirit and psychological level, and the investment of technical and financial resources cannot reach the expected goal.

Play the Role of Information Education in the Innovative Education at Colleges and Universities. Innovation is to promote the basic means for the development of new technology, technology innovation is the foundation, if the system cannot be prepared in advance may appear in issues related to the ultimate goal, in order to better play the advantage and function of information technology to improve the relevant system of education, various systems to accommodate each other, keep up with the era of development, but also to establish the information system of the certain standard and strict, better cultivate students' innovation consciousness, let students can better 
play their own potential.

Innovative Education Methods. Reforming old teaching methods, use of information technology teaching, make full use of information technology teaching is key to cultivate students' innovation ability, is a way to train the innovation ability, innovation education is not only students, but knowledge discovery process, trains the student to solution to solve the problem. For teachers, we must reform the teaching mode of teaching materials as the center, to use some teaching methods to improve students' creative thinking, inspire students to guide students' creative thinking. This allows more students to dare to innovate, rather than rigid memory.

Training Innovative Teachers. The biggest characteristics of education information is to realize the knowledge of digital can not only learn knowledge in books, and shortened the distance between student and teacher, so that students can better contact the teacher to solve the problem. With the advance of information technology in education, teaching first-line teachers and higher, in order to better use of information technology teaching teacher must first of all to have the ability to do this, especially some old teachers change the traditional teaching way of thinking is a bit difficult, but only the education information as their own habits, in order to better the education information to good use in practical teaching.

Promote the Development of Excellent Shared Resources. As one of the major contents of constructing education information, high-quality teaching resources are the major measures for colleges and universities to improve teaching quality. In today's society, colleges obtain their status with knowledge capitals, so they should set themselves as an example to others, following the principle of opening and sharing teaching concepts to establish excellent teaching resources.

\section{Conclusions}

We all know that since the information society at the end of the 20th century, the multimedia computer and network communication technology are gradually widely used in more and more fields, and are more and more inseparable from our daily life. Education information demonstrates its unique advantages in cultivating innovative talents, and colleges and universities should take cultivating innovative talents as the core in the future and utilize modern teaching means to realize the leaping development of China's education. Meanwhile, it is well applied to economy, medical and military fields, but the effects are not so obvious in some other departments, and most of them only use the means with little effect on improving education capacity. Thus, there is still a huge gap to realize the ideal target. In order to find a truly accessible way to reform the education system, it is necessary to use in-depth integration to replace the integration concept instead of just changing educational means. For many years, we have learned many useful experience from the actual application of overseas information education, but if we are unable to find the key of "changing the teaching structure of traditional structure and establishing a new teaching mode", it is rather difficult to make some achievements and we will also pay for it. We must pay attention to this rule and follow it.

\section{References}

[1] Y.G. Guo. Preliminary study on the cultivation of educational information and creative talents[J]. China Educational Technology and equipment.2009 (09).

[2] C. Huang, Z.Q. Zheng. Discussion on the mode of education information and innovative talents cultivation in higher education[J]. Journal of Chongqing University of Science and Technology.

[3] J. Wei. Thinking about the cultivation of innovative talents in Applied Universities and colleges.2013 (04): [J]. Science \& Education Exchange, 2013(04).

[4] Z.K. Yang, Y.H. Wu. On information technology and contemporary education in the depth of the integration of $[\mathrm{J}]$. education research.2014 (03) 
[5] $\mathrm{Yu} \mathrm{Yu.} \mathrm{Technology} \mathrm{innovation} \mathrm{education} \mathrm{in} \mathrm{the} \mathrm{third} \mathrm{session} \mathrm{of} \mathrm{the} \mathrm{session} \mathrm{of} \mathrm{the} \mathrm{Foshan}$ Education Expo intelligent education and learning revolution forum lecture $[\mathrm{J}]$. China Audio Visual Education 2011 71-6.

[6] Gu Gu. Educational technology and education in twenty-first Century[J]. China Audio Visual Education 1995,838-41.

[7] He University of science and technology innovation education and its library[J].Hebei science and Technology Park (01) (2005).

[8] X.G. Qian. Thinking on the subject of innovative education in Colleges and universities[J]. China electronic education. 2004 (03).

[9] H. Song, Q.T. Li. Give full play to the role of Library in the innovation education of higher education [J]. Journal of Baotou Vocational \& Technical College. 2004 (02).

[10]H.Q. Yang, H.W. Li, Xu Jia Yi. The principle and content of the evaluation of the effect of the implementation of innovative education in Colleges and universities[J]. Journal of Hebei Normal College of Vocational Technics (02) 2003. 